\title{
MOLECULAR CHARACTERISATION OF EPIZOOTIC HAEMORRHAGIC DISEASE VIRUS ASSOCIATED WITH A TUNISIAN OUTBREAK AMONG CATTLE IN 2006
}

\author{
Sameh Ben Dhaou ${ }^{1,2,4}$, Corinne SAIlleau ${ }^{1}$, Besma BabaY ${ }^{2}$, Cyril Viarouge ${ }^{1}$, \\ Soufien SGHAIER ${ }^{2}$, Stephan ZIENTARA ${ }^{1}$, Salah HAMMAMI ${ }^{2,3}$ and Emmanuel BRÉARD ${ }^{1 *}$ \\ ${ }^{1}$ Anses, INRA, ENVA, UPEC, UMR 1161 Virology, 23 avenue du général du Gaulle, \\ 94706 Maisons-Alfort, France; ${ }^{2}$ IRVT, Tunis-La Rabta, Tunisia; ${ }^{3}$ ENMV, Sidi Thabet, \\ Tunis, Tunisia - under the tutelage of Manouba University, Tunisia; ${ }^{4}$ Faculty of Sciences \\ of Bizerte, Jarzouna Bizerte, Tunisia - under the tutelage of Carthage University, Tunisia
}

(Received 9 March 2015; accepted 28 October 2015)

In 2006, epizootic haemorrhagic disease (EHD) outbreaks were recorded in the Maghreb (Tunisia, Morocco and Algeria) among cattle, resulting in severe repercussions on herds (oedema of the head, necrotic lesions of the oral mucosa, hyperthermia of the teats, accompanied by anorexia and respiratory distress) and economic losses. The present study gives new information on the molecular characterisation of the EHD virus (EHDV) that had circulated in Tunisia. Genome segments 2, 3, 6, 7 and 10 of EHDV, corresponding to the VP2, VP3, VP5, VP7 and NS3/NS3A proteins, respectively, were amplified from the blood of one animal by RT-PCR and sequenced. Nucleotide sequence comparisons of these five segments with sequences available in the GenBank demonstrated that an EHDV serotype 6 (EHDV-6) had been present in Tunisia in 2006. The possible origin of this strain is discussed.

Key words: Epizootic haemorrhagic disease virus, serotype 6, RT-PCR, sequencing, phylogenetic tree

Epizootic haemorrhagic disease (EHD) is an infectious, non-contagious disease of ruminants. It is caused by EHDV, which belongs to the genus Orbivirus and the family Reoviridae (Mertens et al., 2005). The disease was initially identified and reported in white-tailed deer in New Jersey (USA) in 1955 (Shope et al., 1960).

The genus Orbivirus includes other viruses of veterinary interest such as bluetongue virus (BTV) or African horse sickness virus (AHSV) (Bréard et al., 2013). EHDV shares structural, antigenic and molecular similarities with BTV (MacLachlan and Osburn, 2004). Both viruses are transmitted to their host range (ruminants) by the bites of Culicoides midges. The clinical signs caused by EHDV

\footnotetext{
*Corresponding author; E-mail: emmanuel.breard@anses.fr; Phone: 0033 (149) 772-707
} 
are considered difficult to distinguish from those due to BTV (Savini et al., 2011). Since their discovery, these two viruses have been proven to produce similar clinical diseases in cattle in all respects. Co-infection by the two viruses (BTV and EHDV) has been demonstrated in different studies (Sailleau et al., 2012; Schroeder et al., 2013; Toye et al., 2013; Viarouge et al., 2014). The use of specific diagnostic tools is essential to differentiate between infections with these two viruses.

Twenty-seven BTV and seven EHDV serotypes have been identified so far (Anthony et al., 2009b; Zientara et al., 2014). EHDVs (serotypes 1, 2 and 6) are endemic in North America but only induce clinical signs in certain species of deer (MacLachlan and Osburn, 2004). Several strains of EHDV-2, 6 and 7 can also cause a severe disease in cattle (Ohashi et al., 2002; Bréard et al., 2004; Yadin et al., 2008; Sailleau et al., 2012). Since 2006, in countries close to Europe, EHDVs have been detected in cattle showing clinical signs (Temizel et al., 2009). More precisely, during 2006, outbreaks of EHDV-6 were reported in cattle from Turkey, Morocco, Algeria, and Jordan (European Food Safety Authority, 2007). The infected animals presented clinical signs similar to those described for EHD in Japan, with low case fatality. During the autumn of 2006, the identification of an EHDV-7 causing significant clinical signs in cattle was reported in Israel for the first time (Yadin et al., 2008). This virus is now generally recognised as a potential threat for the cattle breeding industry.

EHDV is an icosahedral virus composed of 10 segments of doublestranded RNA that encode seven structural (VP1-VP7) and four non-structural (NS1-NS3/NS3a) proteins (Mertens et al., 2005). The smallest genome segment (S) 10 (S10) encodes the NS3 viral protein that mediates the release of virus particles from infected cells and plays a role in virulence and vector competence. VP2 and VP5 (encoded by S2 and S6, respectively) are components of the EHDV outer capsid (Huismans et al., 1979; Mecham and Dean, 1988). VP2 is principally involved in virus attachment and penetration of the host cell during infection (Kahlon et al., 1983; Roy, 1989). VP2 is the most variable of the viral proteins (Huismans et al., 2004; Singh et al., 2004; Maan et al., 2007) and determines the serotype (Huismans et al., 1987; Mertens et al., 1989, 2005). The virus core is made up of VP1, VP3, VP4, VP6 and VP7, encoded by genome S1, 3, 4, 9 and 7, respectively (Huismans et al., 1979; Mecham and Dean, 1988). VP3 forms the innermost subcore capsid shell and controls the organisation of the capsid structure (Mertens and Diprose, 2004). VP7 is the main immunodominant viral protein in each of the Orbivirus species, and therefore represents an efficient target for group-specific serological diagnosis (Thevasagayam et al., 1996; Mecham and Jochim, 2000; Luo and Sabara, 2005).

In early September 2006, an emerging disease causing significant morbidity in cattle was observed in Tunisia. Serological analyses suggested that these animals were infected by EHDV (Hammami et al., 2007). Some blood samples were collected from cattle and stored at $-80{ }^{\circ} \mathrm{C}$ until 2012. The main objectives 
of this study were to demonstrate that an EHDV was circulating in Tunisia in 2006, to determine its serotype and the nucleotide sequence of 5 RNA segments, and to compare them with EHDV sequences available in GenBank.

\section{Materials and methods}

\section{Blood samples}

In 2006, 49 EDTA blood samples were collected from cattle in farms found EHDV positive by ELISA (Hammami et al., 2007) and these whole blood samples were stored (without treatment or washing) at $-80^{\circ} \mathrm{C}$. The serological status of these animals was unknown.

\section{Nucleic acid sample preparation, RT-PCR reactions and sequencing}

Total RNA was extracted from $100 \mu$ of the 49 bovine blood samples using the QIAcube robot (QIAGEN) and the QIAamp Viral Kit (Qiagen) according to the manufacturer's instructions. Finally, the RNAs were eluted with $60 \mu 1$ of ultrapure water and used in a specific EHDV real-time RT-PCR (RT-qPCR).

\section{EHD group-specific RT-qPCR}

The EHDV RT-qPCR was performed using a commercial RT-qPCR kit (VetMax EHDV, Life Technologies, France) according to the manufacturer's instructions. This kit allows detection of all EHDV serotypes (by amplifying the EHD S9 encoding VP6) and does not cross-react with bluetongue virus. Five $\mu 1$ of eluted RNA was denatured by heating $\left(95^{\circ} \mathrm{C}, 3 \mathrm{~min}\right)$ in the presence of $10 \%$ DMSO and added to $20 \mu 1$ of VetMax EHDV mix.

\section{EHDV segments 2, 3, 6, 7 and 10 RT-PCRs}

Specific primer pairs (sequences described in Table 1), derived from the nucleotide sequence data of genome segments of EHDV available in GenBank, were used in conventional RT-PCR using the One-step RT-PCR Kit (Qiagen, Courtaboeuf, France). Briefly, $2.5 \mu 1$ of denatured RNA were added to a mixture containing $15.2 \mu \mathrm{l}$ of RNase-free water, $5 \mu \mathrm{l}$ of $5 \mathrm{X}$ QIAGEN One-Step RT-PCR buffer, $1 \mu \mathrm{l}$ of dNTP mix ( $400 \mu \mathrm{M}$ of each dNTP), $0.6 \mu \mathrm{M}$ of each primer, and $1 \mu \mathrm{l}$ of QIAGEN One-Step RT-PCR Enzyme. The amplification was carried out according to the following cycling parameters: $50^{\circ} \mathrm{C}$ for $30 \mathrm{~min}, 95^{\circ} \mathrm{C}$ for $15 \mathrm{~min}$, followed by 40 cycles of $1 \mathrm{~min}$ at $94{ }^{\circ} \mathrm{C}, 1 \mathrm{~min}$ at $56^{\circ} \mathrm{C}$ and $1 \mathrm{~min}$ at $72{ }^{\circ} \mathrm{C}$. An aliquot of $6 \mu 1$ of the RT-PCR product was analysed by electrophoresis on a $2 \%$ agarose gel. 


\section{Sequencing}

Amplified RT-PCR products were sequenced directly, in both directions, using the primer pairs indicated in Table 1. The sequence obtained was then aligned and compared to the corresponding sequences using the Clustal Megalign software (Higgins et al., 1988). Sequences were assembled by SeqMan (DNAstar programs, Lasergene) and compared (Blastn 2.2.23) to the sequences available in GenBank. Sequence alignments were performed using the MegAlign Clustal V method (DNAstar software) and bootstrap analysis.

Table 1

Sequence of primers used for amplification and sequencing of segments 2, 3, 6, 7 and 10 of the Tunisian EHDV-6 strain

\begin{tabular}{|c|c|c|c|c|}
\hline Segment & Sense & Names of primers & Sequence & Localisation \\
\hline \multirow[t]{6}{*}{2} & Sense & Tu EHD6 P1 & GTTAAATTGTTCCAGGATG & $1-19$ \\
\hline & & Tu EHD6 P2 & CATCAATGGCGAATGGC & $1483-1499$ \\
\hline & & Tu EHD6 P3 & CGAAGGTGCGGGAAGCG & $2229-2245$ \\
\hline & Antisense & Tu EHD6 M1 & CAAGAATGTGATACGAGC & $418-401$ \\
\hline & & Tu EHD6 M2 & GGCTAACTGGCACAATC & $2384-2368$ \\
\hline & & Tu EHD6 M3 & CCAGGTAATCTCTGTCAC & $2957-2970$ \\
\hline \multirow[t]{9}{*}{3} & Sense & VP3 F 1 & AATTTCCRGAGCGATGGC & $5-22$ \\
\hline & & VP3 F 2 & CGTGCTTACCDACAGGAG & 895-912 \\
\hline & & VP3 F 3 & WGATATGCAGCAGATGGC & $1846-1864$ \\
\hline & & VP3 F 4 & TACCATTTCATATGGTCCG & $1570-1588$ \\
\hline & Antisense & VP3 R 1 & TGGRTCCATTCTTTCRCCC & $1112-1094$ \\
\hline & & VP3 R 2 & TGYGAATGCGCTARATCCA & 1984-1966 \\
\hline & & VP3 R 3 & GTAAGTGTATTYCCRGTGC & $2768-2750$ \\
\hline & & VP3R 4 & CTAGCTTGGTGCCCACC & $2700-2684$ \\
\hline & & VP3 R 5 & AAGGCAACCCTATCCACC & $2031-2014$ \\
\hline \multirow[t]{4}{*}{6} & Sense & EHDV 6 S6 F & GTTAAAAAGATCCAGTGCCG & $1-21$ \\
\hline & & EHDV 6 S6 F2 & GGAGATAGCTGGCATGAG & $682-699$ \\
\hline & Antisense & EHDV 6 S6 R & TTCGGTTGTATTTTCGGCG & $870-851$ \\
\hline & & EHDVS6 R2 & AAGTTGAAGATCCGAATACC & $1640-1620$ \\
\hline \multirow[t]{2}{*}{7} & Sense & VP7 F1 & TTTGGTGAAGATGGACACG & $8-27$ \\
\hline & Antisense & VP7 R1 & AAGTTGAATTTGGGAAGACG & $1160-1141$ \\
\hline \multirow[t]{2}{*}{10} & Sense & EHDV S10 F & GTTAAAAAGAGGTTGGCGTC & $1-21$ \\
\hline & Antisense & EHDV S10 R & AAGTGTGTCGGAGGATGGC & $808-782$ \\
\hline
\end{tabular}

\section{Virus isolation}

Isolation assays were performed in embryonated chicken eggs (ECEs) or $\mathrm{KC}$ cells (C. sonorensis larvae cells) as described previously (Bréard et al., 2013). Briefly, five ECEs were intravenously inoculated with $100 \mu 1$ of EHDV 
RT-qPCR positive blood samples and incubated for 7 days at $35^{\circ} \mathrm{C}$. The embryos were then homogenised in a sterile MEM medium, centrifuged at $2500 \mathrm{~g}$ for 3 min and then tested by EHDV RT-qPCR.

KC cells were also inoculated with $100 \mu 1$ of EHDV RT-qPCR positive samples and incubated at $27^{\circ} \mathrm{C}$ for 10 days. After incubation, $\mathrm{KC}$ cells and supernatants were collected for EHDV RT-qPCR analyses.

\section{Results}

\section{EHD RT-PCR and isolation}

After RNA extraction from the 49 blood samples, only 4 contained nondegraded RNA (data not shown). Two out of these 4 blood samples were found to be EHDV RT-qPCR positive (with Ct values of 28 and 34).

From one of the EHD RT-qPCR positive blood samples (from cattle located in the Tozeur area and having a $\mathrm{Ct}$ value of 28), amplification products of 5 genes encoding VP2, 5, 3, 7 and NS3 were obtained by conventional RT-PCR. The complete coding sequences of these 5 virus segments were submitted to GenBank. The assigned accession numbers are KC 986822 (for S2), KC 986823 (S6), KC 986825 (S3), KC 986824 (S7), and KC 986826 (S10).

Unfortunately, isolation, by passage of the virus through $\mathrm{KC}$ cells or ECE, failed.

\section{Sequencing}

The nucleotide sequences of these five coding segments were compared to sequences available in GenBank to determine genetic heterogeneity between the EHDV Tunisian strain and other EHDV strains.

Segment 2 (VP2). The nucleotide (NT) sequence of the Tunisian EHDV S2 belongs to serotype 6 (Fig. 1, Table 2). More specifically, this sequence is close to the EHDV Moroccan or Algerian S2 (99.9 and 100\% of NT homology, respectively). Sequence data showed that the Tunisian, South African, Reunion Island and Bahrain EHDV-6 strains are also close (between 96.7 and 97.2\% of NT sequence homology). These degrees of homology decrease considerably with the EHDV-6 strains from Guadeloupe (the Caribbean), USA and Australia (67.9, 68.0 and $68.1 \%$, respectively).

The S2 of the EHDV-8 (from Australia) is also included in this 'EHDV-6 cluster', showing $65.4 \%$ of NT identity with the S2 Tunisian EHDV-6 strain. The S2 of the five other serotypes shows only between 34.5 and $36.4 \%$ of NT homology with the Tunisian EHDV-6 S2 sequence.

Segment 6 (VP5). Phylogenetic analysis of EHDV S6 sequences shows distinct clusters at nucleotide level (Fig. 2, Table 2). The Tunisian S6 coding se- 
quence shares similar levels of identity with the South African or Bahrain EHDV-6 strains (97.3 and 96.1\% NT homology). With other EHDV-6 serotypes from the USA (wild or reassortant strains) or from Australia, the NT homologies decrease to between 78.7 and $78.2 \%$. A similar percentage of NT identity was obtained with the EHDV-8 from Australia (76.9\%). Regarding the S6 from other EHDV serotypes, the percentage of NT identity decreases to levels ranging from 56.4 to $64.3 \%$.

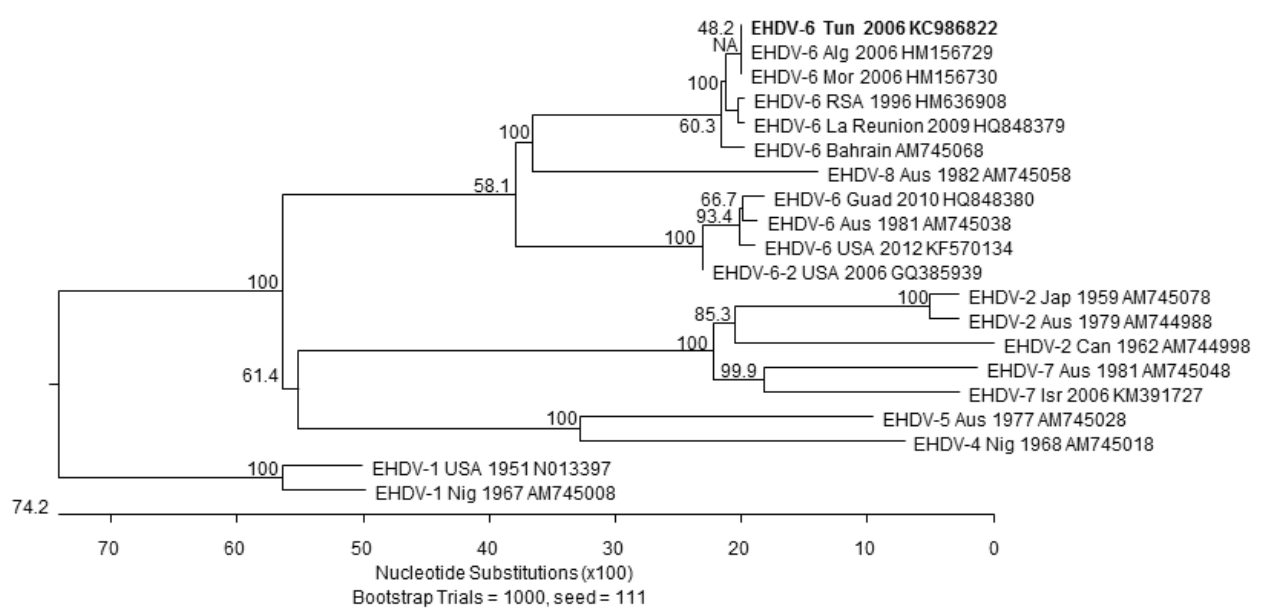

Fig. 1. Phylogenetic tree of nucleotide-coding sequences of segment 2 showing relationships between EHDV serotypes. The serotype, country of origin, years of isolation and the accession number are indicated in each sequence name. The Tunisian sequences are indicated in bold

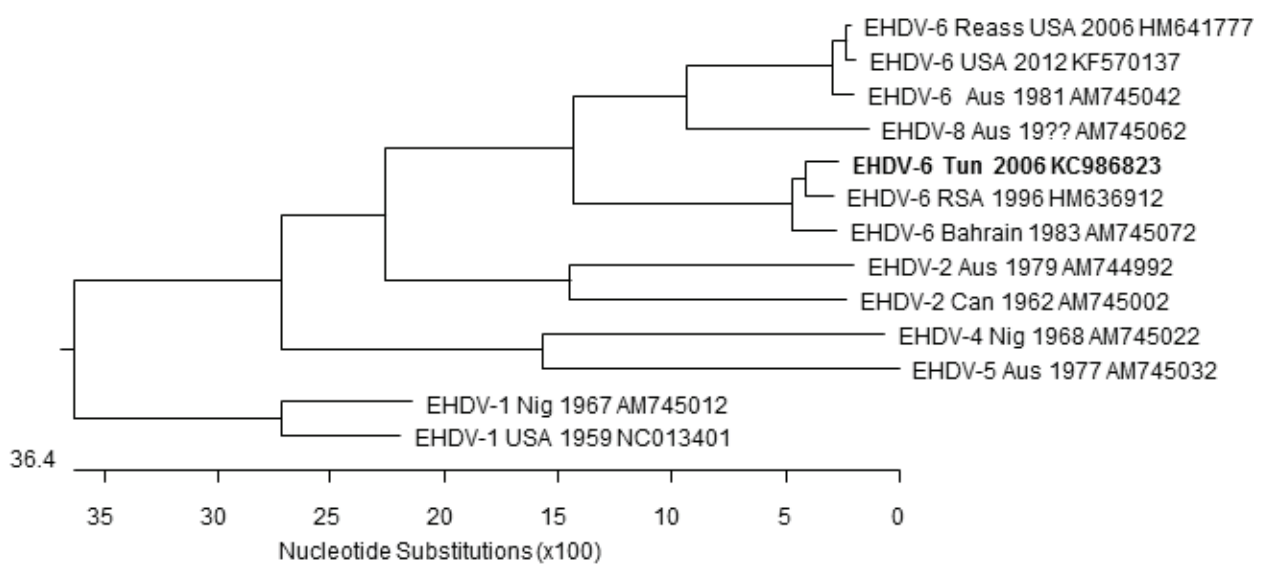

Fig. 2. Phylogenetic tree of nucleotide-coding sequences of segment 6 showing relationships between EHDV serotypes. The serotype, country of origin, years of isolation and the accession number are indicated in each sequence name. The Tunisian sequences are indicated in bold 
BEN DHAOU et al

Table 2

List of EHDV strains used for phylogenetic analyses

\begin{tabular}{|c|c|c|c|}
\hline Serotype & Country & $\begin{array}{l}\text { Year of } \\
\text { isolation }\end{array}$ & Name of strain \\
\hline EHDV-1 USA & USA & 1955 & New Jersey \\
\hline EHDV-1 USA & USA & 1955 & New Jersey \\
\hline EHDV-1 USA & USA & 1959 & New Jersey \\
\hline EHDV-1 Nig & Nigeria & 1967 & IbAr 22619 \\
\hline EHDV-2 USA & USA & 2000 & CC 126-00 \\
\hline EHDV-2 AUS & Australia & 1979 & 439 \\
\hline EHDV-2 AUS & Australia & 1991 & Australian serotype 2 \\
\hline EHDV-2 Can & Canada & 1962 & Alberta \\
\hline EHDV-2 Can & Canada & 1962 & Alberta \\
\hline EHDV-2 Jap & Japan & 1959 & Ibaraki Jap 1959/01 \\
\hline EHDV-2 Jap & Japan & 1997 & KSB-14/E/97 \\
\hline EHDV-4 Nig & Nigeria & 1968 & IbAr 33853 \\
\hline EHDV-5 Aus & Australia & 1977 & CSIRO 157 \\
\hline EHDV-5 Aus & Australia & 1977 & CSIRO 157 \\
\hline EHDV-6 Mor & Morocco & 2006 & A113/06 \\
\hline EHDV-6 Alg & Algeria & 2006 & $2006 / 02$ \\
\hline EHDV-6 Tun & Tunisia & 2006 & Tunisia 2577 \\
\hline EHDV-6 Bahrain & Bahrain & 1983 & Strain 318 \\
\hline EHDV-6 Reunion & Reunion Island & 2003 & EHDV-6/2003 \\
\hline EHDV-6 Reunion & Reunion Island & 2009 & EHDV-6/09.01 \\
\hline EHDV-6 Guad & Guadeloupe Island & 2010 & Guadeloupe 5124 \\
\hline EHDV-6 Aus & Australia & 1981 & CSIRO 753 \\
\hline EHDV-6 USA & USA & 2012 & C/Cervidae/OHIO/12-3437-8/2012 \\
\hline EHDV-6 RSA & South Africa & 1996 & M44/96 \\
\hline $\begin{array}{l}\text { EHDV-6/ } \\
\text { EHDV-2 Reassortant }\end{array}$ & USA & 2006 & CC 304-06 \\
\hline EHDV-7 Isr & Israel & 2006 & ISR 2006/13 \\
\hline EHDV-7 Isr & Israel & 2006 & Isr 2006/04 \\
\hline EHDV-7 Isr & Israel & 2006 & Isr 2006/02 \\
\hline EHDV-7 Aus & Australia & 1981 & CSIRO 775 \\
\hline EHDV-8 Aus & Australia & 1982 & CPR 3961A \\
\hline
\end{tabular}

Segment 7 (VP7). The Tunisian EHDV-6 S7 belongs to the same cluster as the S7 of EHDV-6 detected in Reunion Island, South Africa and Bahrain (NT identity ranged from 98.7 to $97.3 \%$; see Fig. 3 and Table 2). S7 of the North 
American EHDV-2 strains shows $90.7 \%$ and $91.4 \%$ NT identity with the Tunisian S7. The S7 from EHDV isolated in Japan, Australia, USA (serotype 1), Nigeria or Israel shows 79.5 to $75.8 \%$ NT identity with the Tunisian S7.

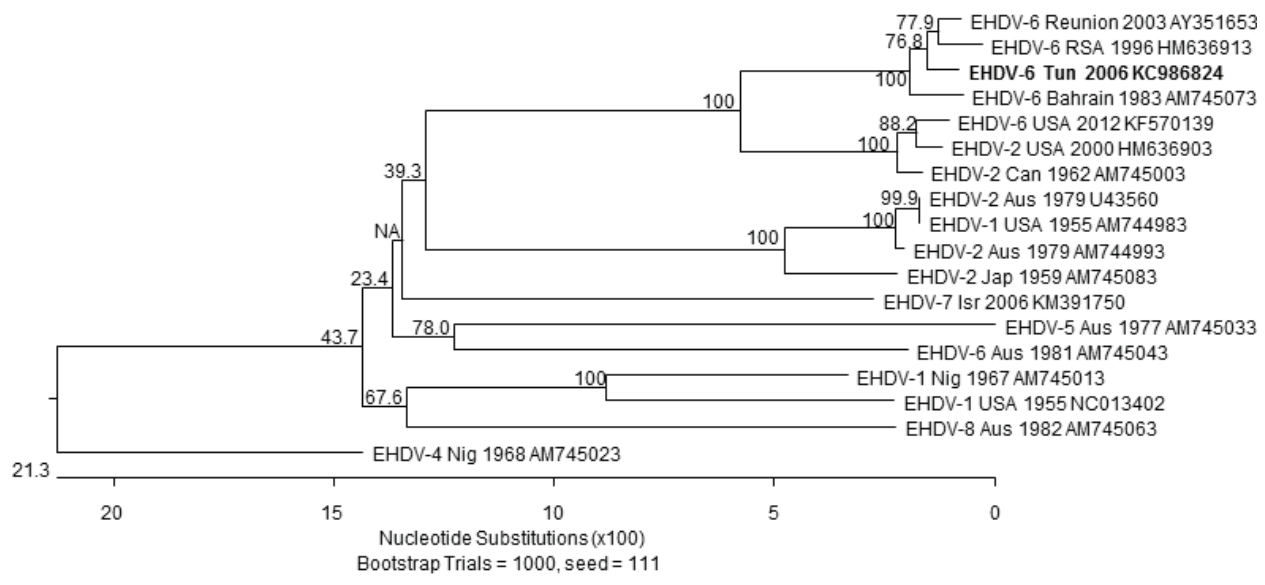

Fig. 3. Phylogenetic tree of nucleotide-coding sequences of segment 7 showing relationships between EHDV serotypes. The serotype, country of origin, years of isolation and the accession number are indicated in each sequence name. The Tunisian sequences are indicated in bold

Segment 10 (NS3). As performed with S7, the Tunisian EHDV S10 sequence was compared with EHDV S10 available in GenBank (Fig. 4, Table 2). The Tunisian EHDV S10 clusters with S10 of EHDV-6 from Reunion Island, Bahrain and EHDV-7 from Israel (NT homology between 95.1 and 95.3\%). These percentages of similarity decrease with EHDV-1, 2 and 6 detected in North America (NT homology ranged from 86.8 to $87.2 \%$ ). With other strains isolated in Australia, Japan and Nigeria, the NT identity of their EHDV S10 ranged between 72.5 and $74.2 \%$ when compared with the Tunisian EHDV S10.

Segment 3 (VP3). Segment 3 nucleotide sequence of Tunisian EHDV-6 was compared with 16 other similar sequences available in GenBank (Fig. 5, Table 2). The Tunisian EHDV-6 S3 topotypes strongly according to its geographical origin, independently of the EHDV serotype. The highest percentages of NT identity were observed with S3 of the Nigerian EHDV-4 and EHDV-1 strains (97.0 and 95.5\%, respectively). With EHDV-7 and 6 detected in Israel, Bahrain and South Africa, the percentage of NT identity decreases (ranging from 92.9 to 92.0\%). High NT identity (ranging from 91.1 to $90.9 \%$ ) is also observed with EHDV strains (serotype 1 or 2) isolated in North America. The lowest percentages of homology were observed with EHDV strains isolated in Australia or Japan (between 78.2 and $78.9 \%$ of NT identity with the Tunisian S3 nucleotide sequence). 


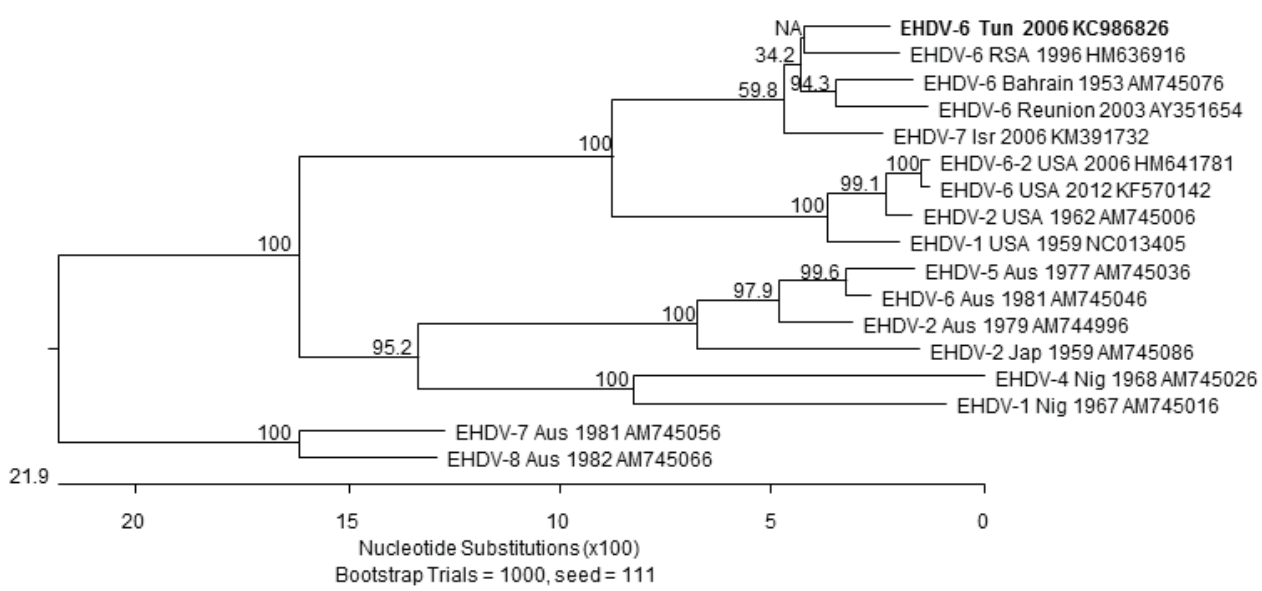

Fig. 4. Phylogenetic tree of nucleotide-coding sequences of segment 10 showing relationships between EHDV serotypes. The serotype, country of origin, years of isolation and the accession number are indicated in each sequence name. The Tunisian sequences are indicated in bold

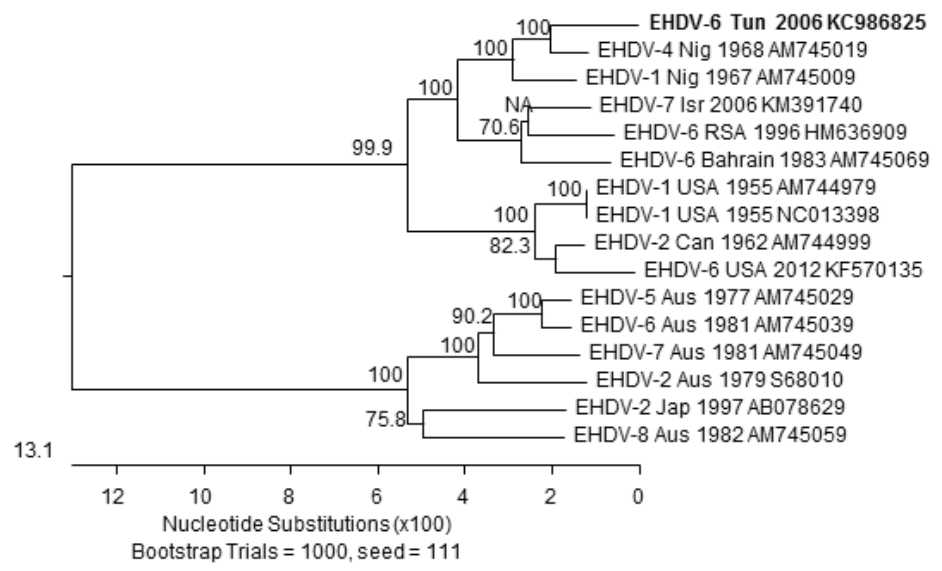

Fig. 5. Phylogenetic tree of nucleotide-coding sequences of segment 3 showing relationships between EHDV strains. The serotype, country of origin, years of isolation and the accession number are indicated in each sequence name. The Tunisian sequences are indicated in bold

\section{Discussion}

In September 2006, a novel disease syndrome in cattle was observed in Tunisia (Hammami et al., 2007). A specific EHDV ELISA developed by Thevasagayam et al. (1996) was performed on sera from cattle showing clinical signs, and the results showed that $68 \%(24 / 35)$ of these sick animals were EHDV ELISA positive (Hammami et al., 2007). However, no EHDV genome detection was performed at that time. 
Blood samples from 49 cattle on 24 affected farms, which had been stored at $-80{ }^{\circ} \mathrm{C}$, were analysed in 2012 by RT-qPCR. One of the two positive RTqPCR blood samples showed levels of RNA sufficient to amplify five different RNA genome segments of EHDV. The serological status of the 49 animals was unknown and no ELISA could be performed on these frozen blood samples. Assays to isolate the virus by passage through $\mathrm{KC}$ cells or ECE were unsuccessful, possibly due to the storage of this blood for 8 years at $-80^{\circ} \mathrm{C}$. However, the molecular results demonstrate the presence of EHDV-6 in Tunisia in 2006.

The nucleotide coding sequence of the EHDV Tunisian S2 demonstrates that it belongs to serotype 6 . As observed by Anthony et al. (2009b), phylogenetic analyses of EHDV nucleotide $\mathrm{S} 2$ sequences shows four groups. The group containing the different EHDV-6 S2 also contains the S2 from serotype 8. In this group, two clusters are observed: one contains six EHDV-6 strains, each detected in Africa (South Africa and the Maghreb) or close to Africa, i.e. the Arabian Peninsula (Bahrain) and the Indian Ocean (Reunion Island), while the second cluster contains four other EHDV-6 strains isolated in Australia, USA and the Caribbean. These two clusters do not reflect East/West groupings corresponding to those described by Anthony et al. (2009b), but it seems that the S2 of the EHDV6 isolated in Africa, the Arabian Peninsula and the Indian Ocean have a common origin while the Australian, North American and Caribbean strains have a different one. Similar data were obtained by S6 sequence comparisons: EHDV-6 S6 strains isolated in Africa or the Arabian Peninsula form a cluster separate from those detected in Australia or North America. Altogether, comparisons of all EHDV genome segments 2 and 6 (encoding the outer coat proteins of the virus particle) suggest only two different origins for these two segments, which determine the EHD serotype 6.

As already observed for BTV and EHDV (Anthony et al., 2009c), S3 sequences topotype very strongly in accordance with their eastern or western origins and there is also some clustering of segment 3 into finer geographic subgroups (Cheney et al., 1995; Anthony et al., 2009a). Interestingly, the S10 alignment also suggests a 'geographical' subgroup, with S10 of EHDV detected in Tunisia, Bahrain, Reunion Island and Israel (serotype 7) showing high NT homology. Alignment of S7 of EHDV strains also shows a cluster for the EHDV-6 isolated in Tunisia, Reunion Island, Bahrain, and South Africa.

Segment 2 sequence analyses indicate that the EHDV-6 strain circulating in Tunisia in 2006 likely had the same origin as the EHDV-6 that circulated in Morocco and Algeria during 2006. It would be of interest to compare the S3, 6, 7 and 10 nucleotide sequences of these EHDV-6 strains isolated in the Maghreb: these data were not available in GenBank. Altogether, the S2, 3, 6, 7 and S10 comparison results suggest that these 5 EHDV-6 Tunisian segments have a common origin with EHDV strains isolated in the same geographic area (Africa, Arabian Peninsula and Indian Ocean). 
This study also suggests that it is important to build a database of EHDV genome sequences in order to characterise the viruses and to enable molecular epidemiology studies.

\section{Acknowledgements}

We thank the veterinarians and technicians participating in this study, who collected blood samples in the field and performed the serological analyses. We also thank the PHC Utique programme (No. 24849SB) for their financial support. The authors declare no conflicts of interest with respect to the research, authorship and publication of this article.

\section{References}

Anthony, S. J., Maan, N., Maan, S., Sutton, G., Attoui, H. and Mertens, P. P. C. (2009a): Genetic and phylogenetic analysis of the core proteins VP1, VP3, VP4, VP6 and VP7 of epizootic haemorrhagic disease virus (EHDV). Vir. Res. 145, 187-199.

Anthony, S. J., Maan, N., Maan, S., Sutton, G., Attoui, H. and Mertens, P. P. C. (2009b): Genetic and phylogenetic analysis of the outer capsid proteins VP2 and VP5 of epizootic haemorrhagic disease virus (EHDV). Vir. Res. 145, 200-210.

Anthony, S. J., Maan, N., Maan, S., Sutton, G., Attoui, H. and Mertens, P. P. C. (2009c): Genetic and phylogenetic analysis of the non-structural proteins NS1, NS2 and NS3 of epizootic haemorrhagic disease virus (EHDV). Vir. Res. 145, 211-219.

Bréard, E., Sailleau, C., Hamblin, C., Graham, S. D., Gourreau, J. M. and Zientara, S. (2004): Outbreak of epizootic haemorrhagic disease on the island of Reunion. Vet. Rec. 155, 422-423.

Bréard, E., Belbis, G., Viarouge, C., Riou, M., Desprat, A., Moreau, J., Laloy, E., Martin, G., Sarradin, P., Vitour, D., Batten, C., Doceul, V., Sailleau, C. and Zientara, S. (2013): Epizootic hemorrhagic disease virus serotype 6 experimentation on adult cattle. Res. Vet. Sci. 95, 794-798.

Cheney, I. W., Larson, M. D., Mecham, J. O. and Wilson, W. C. (1995): Geographical genetic variation in the gene encoding VP3 from the Alberta isolate of epizootic hemorrhagic disease virus. Vir. Res. 36, 279-286.

European Food Safety Authority (2007): Scientific opinion on epizootic hemorrhagic disease [cited 2007 Oct 21]. http://www.efsa.europa.eu/en/scdocs/doc/1418.pdf

Hammami, S., Sghaier, S., Chérif, N., Berguaoui, R., Hammami, M., Ben Hassen, S. and El Haddouchi, S. (2007): Première incursion du virus de la maladie hémorragique épizootique (EHDV) en Tunisie. Bulletin Vétérinaire de l'Institut de la Recherche Vétérinaire de Tunis 25, 6-7.

Higgins, D. G. and Sharp, P. M. (1988): CLUSTAL: a package for performing multiple sequence alignments on a microcomputer. Gene 73, 237-244.

Huismans, H., Bremer, C. W. and Barber, T. L. (1979): The nucleic acid and proteins of epizootic haemorrhagic disease virus. Onderst. J. Vet. Res. 46, 95-104.

Huismans, H., van der Walt, N. T., Cloete, M. and Erasmus, B. J. (1987): Isolation of a capsid protein of bluetongue virus that induces a protective immune response in sheep. Virol. 157, $172-179$.

Huismans, H., van Staden, V., Fick, W. C., van Niekerk, M. and Meiring, T. L. (2004): A comparison of different orbivirus proteins that could affect virulence and pathogenesis. Vet. Italia 40, $417-425$. 
Kahlon, J., Sugiyama, K. and Roy, P. (1983): Molecular basis of bluetongue virus neutralization. J. Virol. 48, 627-632.

Luo, L. and Sabara, M. I. (2005): Production of a recombinant major inner capsid protein for serological detection of epizootic haemorrhagic disease virus. Clinl. Diag. Lab. Immunol. 12, 904-909.

Maan, S., Maan, N. S., Samuel, A. R., Rao, S., Attoui, H. and Mertens, P. P. C. (2007): Analysis and phylogenetic comparisons of full-length VP2 genes of the 24 bluetongue virus serotypes. J. Gen. Virol. 88, 621-630.

MacLachlan, N. J. and Osburn, B. I. (2004): Epizootic haemorrhagic disease of deer. In: Coetzer, J. A. W. and Tustin, R. C. (eds) Infectious Diseases of Livestock, Volume 2. Second edition. Oxford University Press Southern Africa, Cape Town, South Africa. pp. 1227-1230.

Mecham, J. O. and Dean, V. C. (1988): Protein coding assignment for the genome of epizootic haemorrhagic disease virus. J. Gen. Virol. 69, 1255-1262.

Mecham, J. O. and Jochim, M. M. (2000): Development of an enzyme-linked immunosorbent assay for the detection of antibody to epizootic hemorrhagic disease of deer virus. J. Vet. Diag. Invest. 12, 142-145.

Mertens, P. P. and Diprose, J. (2004): The bluetongue virus core: a nano-scale transcription machine. Virus Res. 101, 29-43.

Mertens, P. P. C., Maan, S., Samuel, A. R. and Attoui, H. (2005): Orbivirus: Reoviridae. In: Fauquet, C. M., Mayo, M. A., Maniloff, J., Desselberger, U. and Ball, L. A. (eds) Virus Taxonomy: VIIIth Report of the ICTV. Elsevier/Academic Press, London. pp. 466-483.

Mertens, P. P. C., Pedley, S., Cowley, J., Burroughs, J. N., Corteyn, A. H., Jeggo, M. H., Jennings, D. M. and Gorman, B. M. (1989): Analysis of the roles of bluetongue virus outer capsid proteins VP2 and VP5 in determination of virus serotype. Virology 170, 561-565.

Ohashi, S., Yoshida, K., Yanase, T. and Tsuda, T. (2002): Analysis of intratypic variation evident in an Ibaraki virus strain and its epizootic hemorrhagic disease virus serogroup. J. Clin. Microbiol. 4, 3684-3688.

Roy, P. (1989): Bluetongue virus genetics and genome structure. Virus Res. 13, 179-206.

Sailleau, C., Zanella, G., Bréard, E., Viarouge, C., Desprat, A., Vitour, D., Adam, M., Lasne, L., Martrenchar, A., Bakkali-Kassimi, L., Costes, L. and Zientara, S. (2012): Co-circulation of bluetongue and epizootic haemorrhagic disease viruses in cattle in Reunion Island. Vet. Microbiol. 23, 191-197.

Savini, G., Afonso, A., Mellor, P., Aradaib, I., Yadin, H., Sanaa, M., Wilson, W., Monaco, F. and Domingo, M. (2011): Epizootic haemorrhagic disease. Res. Vet. Sci. 91, 1-17.

Schroeder, M. E., Johnson, D. J., Ostlund, E. N., Meier, J., Bounpheng, M. A. and Clavijo, A. (2013): Development and performance evaluation of a streamlined method for nucleic acid purification, denaturation, and multiplex detection of Bluetongue virus and Epizootic haemorrhagic disease virus. Vet. Sci. 38, 133.

Shope, R. E., MacNamara, L. G. and Mangold, R. (1960): A virus-induced epizootic hemorrhagic disease of the Virginia white-tailed deer (Odocoileus virginianus). J. Exp. Med. 111, 155-170.

Singh, K. P., Maan, S., Samuel, A. R., Rao, S., Meyer, A. J. and Mertens, P. P. (2004): Phylogenetic analysis of bluetongue virus genome segment 6 (encoding VP5) from different serotypes. Vet. Italia 40, 479-483.

Temizel, E. M., Yesilbag, K.., Batten, C., Senturk, S., Maan, N. S., Mertens, P. P. C. and Batmaz, H. (2009): Epizootic hemorrhagic disease in cattle, Western Turkey. Emerg. Inf. Dis. 15, $317-319$.

Thevasagayam, J. A., Woolhouse, T. R., Mertens, P. P. C., Burroughs, J. N. and Anderson, J. (1996): Monoclonal antibody based competitive ELISA for the detection of antibodies against epizootic haemorrhagic disease of deer virus. J. Virol. Meth. 57, 117-126.

Toye, P. G., Batten, C. A. and Kiara, H. (2013): Bluetongue and epizootic haemorrhagic disease virus in local breeds of cattle in Kenya. Res. Vet. Sci. 94, 769-773. 
Viarouge, C., Lancelot, R., Rives, G., Bréard, E., Miller, M., Baudrimont, X., Doceula, V., Damien Vitour, D., Zientara, S. and Sailleau, C. (2014): Identification of bluetongue virus and epizootic hemorrhagic disease virus serotypes in French Guiana in 2011 and 2012. Vet. Microbiol. 174, 78-85.

Yadin, H., Brenner, J., Bumbrov, V., Oved, Z., Stram, Y., Klement, E., Perl, S., Anthony, S., Maan, S., Batten, C. and Mertens, P. P. C. (2008): Epizootic haemorrhagic disease virus type 7 infection in cattle in Israel. Vet. Rec. 162, 53-56.

Zientara, S., Sailleau, C., Viarouge, C., Höper, D., Beer, M., Jenckel, M., Hoffmann, B., Romey, A., Bakkali-Kassimi, L., Fablet, A., Vitour, D. and Bréard, E. (2014): Novel bluetongue virus in goats, Corsica, France, 2014. Emerg. Inf. Dis. 20, 2123-2125. 